\title{
CSNK2A1 Gene
}

National Cancer Institute

\section{Source}

National Cancer Institute. CSNK2A1 Gene. NCI Thesaurus. Code C24315.

This gene is involved in DNA repair, intercellular communication and signal transduction. 